\title{
The analysis of teaching belief between English lecturers at the Faculty of Economics and Business (FEB) and Faculty of Teacher Training and Education (FKIP) in the University of Lampung (Unila)
}

\author{
Lidya Ayuni Putri' ${ }^{1}$, Rafista Deviyanti², Sri Suningsih3 \\ 1,2,3University of Lampung \\ Correspondence : lidyaayuniputri@yahoo.com
}

\begin{abstract}
Teaching is a dynamic process that involves a quick decision-making process. Teaching is also an activity that refers to what students need. This decision-making process often appears as a reflection of what the teacher believes and as a reflection of the theory adopted by the institution where the teacher works. This study addresses the teachers' beliefs in teaching English at different situation. The method used in this research is qualitative descriptive by using questionnaire and interview as data collection technique. The respondents are two lecturers from FEB Unila and FKIP Unila. The study aims at (1) exploring teachers' beliefs in teaching and learning process at two different faculties, and (2) describing the factors that shape teachers' beliefs in teaching and learning process at two different faculties. The findings showed different beliefs regarding teaching and learning process between two lecturers and stated that college was counted as the contributed factor that shapes their beliefs in English teaching and learning process.
\end{abstract}

Keywords: teaching belief, perception, EFL, English lecturer.

\section{Introduction}

Research on teaching belief is part of the process of understanding how a teacher conceptualizes what the teacher does. To understand the various approaches taken by the teacher, investigating the beliefs that the teacher holds is considered an important factor that must be done (Richards et al., 2001). Bailey and Basturkmen (Basturkmen, 2012) stated that teaching beliefs play an important role in the process of developing teacher professionalism, and teaching practices carried out in class reflect what the teacher believes. This is also supported by Donaghue (Donaghue, 2003) who states that belief is considered important 
The analysis of teaching belief between English lecturers at the Faculty of Economics and Business (FEB) and Faculty of Teacher Training and Education (FKIP) in the University of

because belief affects the acceptance and absorption of new teaching approaches that are accepted by teachers when they are in a process of professional development.

Incecay (Inceçay, 2011) concluded that research on teaching belief includes three (3) basic assumptions, namely:

1. Teacher beliefs affect both teacher perceptions and assessments which in turn influence what the teacher will say and do in the classroom.

2. The teacher's belief plays an important role in relation to the way teachers learn and teach, how teachers interpret new information about teaching and learning, and how to interpret new information into classroom teaching practices.

3. Understanding teaching beliefs is important to improve teaching practices and professional teacher preparation programs.

Teaching belief is something that is related to teachers in the teaching system or belief that is relevant to the teaching carried out by the teacher himself. Teachers' conception of teaching is also influenced by their own perceptions of the teaching environment, such as how influential is what is taught and how teaching is done, and perceptions of how the teaching process will be assessed, as well as class sizes that are not too large and the number of students is not too large (Prosser \& Trigwell, 1997).

Teacher belief influences the interaction between teacher, student, and teaching planning (Wang et al., n.d.). For example, it was found that teachers who have high self-efficacy will not give criticism to their students and will help students who have difficulties in the learning process.

Brunning et al. (White \& Bruning, 2005) concluded that there are three factors that influence their belief in classroom teaching, such as:

1. Belief about lesson content, the point is that teachers plan instruction in a way that is consistent with their assumptions about the material taught in class.

2. Belief towards students, meaning that the teacher forms a strong opinion about students based on physical characteristics, test scores, class performance, social skills, parental attitudes, and student self-efficacy.

3. Belief about teaching, the point is that teachers plan teaching based on what they believe about effective teaching and then carry out instruction in class according to what they have planned.

\section{Belief about language learning inventory (BALLI)}

In the early 1980s, Horwitz developed an instrument to identify beliefs about foreign language learning (Kuntz, 1996). Horwitz examines the relationship between student and teacher goals with learning strategies in either the acquisition of a foreign or a second language for each of these groups. The instrument developed by Horwitz is The Beliefs about Language Learning Inventory (BALLI). The instrument in the form of a questionnaire has been used and adapted by many researchers (Alsamaani, 2012) to collect data about the 
beliefs of students and teachers about the language studied in the situation and different conditions. Since then, the BALLI questionnaire has been widely used by researchers around the world to reveal beliefs such as beliefs about teaching different languages in different cultural contexts.

Horwitz (Horwitz, 1988) stated that in the BALLI questionnaire there are 34 statements representing five themes of belief, namely foreign language aptitude, difficulty of language learning, the nature of language learning, learning and communication strategies, and motivation and expectations. The five themes in the BALLI questionnaire have a number of percentage arrangements that differ from one another. This percentage amount illustrates the difference in the portion of each statement item in the five different belief themes in the BALLI questionnaire. For the theme of foreign language aptitude, it has a percentage of $26.5 \%$, followed by the theme of learning and communication strategies of $23.5 \%$, then the theme of nature of language learning has a total percentage of 20.6\%, and the theme of difficulty of language learning has a percentage of $17.6 \%$, and the theme motivation and expectations in the last order with a total of $11.8 \%$. The division of the items in the questionnaire could be seen in the table below.

Table 1. Different focus of Belief in Horwitz' BALLI Questionnaire

\begin{tabular}{|c|c|c|c|c|}
\hline Theme & $\begin{array}{l}\text { Questio } \\
\mathrm{n} \\
\text { Number }\end{array}$ & Statement & $\begin{array}{l}\text { Total } \\
\text { Amoun } \\
t\end{array}$ & Total \% \\
\hline \multirow{13}{*}{$\begin{array}{l}\text { Foreign } \\
\text { Language } \\
\text { Aptitude }\end{array}$} & 1 & It is easier for children than adults to learn English. & 9 items & 26.5 \\
\hline & 2 & $\begin{array}{l}\text { Some people have special ability for learning } \\
\text { English. }\end{array}$ & & \\
\hline & 10 & $\begin{array}{l}\text { It is easier for someone who already speaks a } \\
\text { foreign language to learn another one. }\end{array}$ & & \\
\hline & 14 & $\begin{array}{l}\text { If someone spent one hour a day learning English, } \\
\text { how long would it for them to learn English very } \\
\text { well? }\end{array}$ & & \\
\hline & & 1. less than a year & & \\
\hline & & 2. 1-2 years & & \\
\hline & & 3. 3-5 years & & \\
\hline & & $\begin{array}{l}\text { 4. 5-10 years } \\
5 \text { You can't learn English in one hour a dav }\end{array}$ & & \\
\hline & 21 & $\begin{array}{l}\text { It is important to practice English with Music or } \\
\text { Movie. }\end{array}$ & & \\
\hline & 28 & $\begin{array}{l}\text { It is easier for my students to read and write English } \\
\text { than to speak and understand it. }\end{array}$ & & \\
\hline & 31 & You can learn English even if you are not motivated. & & \\
\hline & 32 & $\begin{array}{l}\text { People who speak more than one language are very } \\
\text { intelligent. }\end{array}$ & & \\
\hline & 33 & $\begin{array}{l}\text { Students who learn to read in their native language } \\
\text { have more trouble learning to read in English than } \\
\text { students who started reading in English in Earlier } \\
\text { study. }\end{array}$ & & \\
\hline $\begin{array}{l}\text { Difficulty } \\
\text { of }\end{array}$ & 3 & Some languages are easier to learn than others. & 6 items & 17.6 \\
\hline
\end{tabular}


The analysis of teaching belief between English lecturers at the Faculty of Economics and Business (FEB) and Faculty of Teacher Training and Education (FKIP) in the University of

\begin{tabular}{|c|c|c|c|c|}
\hline \multicolumn{5}{|l|}{ Language } \\
\hline & \multirow[t]{6}{*}{4} & \multicolumn{3}{|l|}{ English is: } \\
\hline & & \multicolumn{3}{|l|}{ 1. a very difficult language } \\
\hline & & \multicolumn{3}{|l|}{ 2. a difficult language } \\
\hline & & \multicolumn{3}{|l|}{ 3. a language of medium difficulty } \\
\hline & & \multicolumn{3}{|l|}{ 4. an easy language } \\
\hline & & \multirow{2}{*}{\multicolumn{3}{|c|}{$\begin{array}{l}\text { 5. a very easy language } \\
\text { I believe that my students will learn to speak } \\
\text { English very well. }\end{array}$}} \\
\hline & 6 & & & \\
\hline & 23 & \multicolumn{3}{|l|}{ I want my students to speak English very well. } \\
\hline & 27 & \multicolumn{3}{|l|}{$\begin{array}{l}\text { If my students learn to speak English very well, they } \\
\text { will have better opportunity for a good job. }\end{array}$} \\
\hline & 34 & \multicolumn{3}{|l|}{ Everyone can learn to speak English } \\
\hline \multirow{8}{*}{$\begin{array}{l}\text { Nature of } \\
\text { Language } \\
\text { Learning }\end{array}$} & 5 & $\begin{array}{l}\text { People from my country are good at learning } \\
\text { English. }\end{array}$ & 7 items & 20.6 \\
\hline & 8 & \multirow{2}{*}{\multicolumn{3}{|c|}{$\begin{array}{l}\text { It is necessary to know about English-speaking } \\
\text { cultures to speak English. }\end{array}$}} \\
\hline & & & & \\
\hline & 11 & \multicolumn{3}{|l|}{$\begin{array}{l}\text { It is best to learn English in an English-speaking } \\
\text { country. }\end{array}$} \\
\hline & 15 & \multicolumn{3}{|l|}{$\begin{array}{l}\text { My students will have special ability for learning } \\
\text { English. }\end{array}$} \\
\hline & 19 & \multicolumn{3}{|l|}{$\begin{array}{l}\text { If beginning students are permitted to make errors } \\
\text { in English, it will be difficult for them to speak } \\
\text { correctly later. }\end{array}$} \\
\hline & 24 & \multicolumn{3}{|l|}{ It is easier to speak than understand English. } \\
\hline & 25 & \multicolumn{3}{|l|}{$\begin{array}{l}\text { Learning English is different from learning other } \\
\text { academic subjects. }\end{array}$} \\
\hline \multirow{8}{*}{$\begin{array}{l}\text { Learning } \\
\text { and } \\
\text { Communi } \\
\text { cation } \\
\text { Strategies }\end{array}$} & 7 & $\begin{array}{l}\text { It is important to speak English with a good } \\
\text { pronunciation. }\end{array}$ & 8 items & 23.5 \\
\hline & 9 & \multicolumn{3}{|l|}{$\begin{array}{l}\text { You should not say anything in English until you } \\
\text { can say it correctly. }\end{array}$} \\
\hline & 12 & \multicolumn{3}{|l|}{$\begin{array}{l}\text { I enjoy practicing English with the Native Speakers } \\
\text { I meet. }\end{array}$} \\
\hline & 13 & \multicolumn{3}{|l|}{$\begin{array}{l}\text { It is OK to guess if you do not know a word in } \\
\text { English. }\end{array}$} \\
\hline & 16 & \multicolumn{3}{|l|}{$\begin{array}{l}\text { The most important part of learning English is } \\
\text { learning vocabulary words. }\end{array}$} \\
\hline & 17 & \\
\hline & 18 & \multicolumn{3}{|l|}{$\begin{array}{l}\text { The best way to learn English is by overlearning } \\
\text { with drills. }\end{array}$} \\
\hline & 20 & \multicolumn{3}{|l|}{$\begin{array}{l}\text { The most important part of learning English is } \\
\text { learning the grammar. }\end{array}$} \\
\hline \multirow{4}{*}{$\begin{array}{l}\text { Motivatio } \\
\mathrm{n} \text { and } \\
\text { Expectati } \\
\text { ons }\end{array}$} & 22 & $\begin{array}{l}\text { Women are better than men at learning foreign } \\
\text { languages. }\end{array}$ & 4 items & 11.8 \\
\hline & 26 & \multicolumn{3}{|l|}{$\begin{array}{l}\text { The most important part of learning English is how } \\
\text { to translate from my native language. }\end{array}$} \\
\hline & 29 & \multicolumn{3}{|l|}{$\begin{array}{l}\text { People who are good at mathematics or science are } \\
\text { not good at learning foreign languages. }\end{array}$} \\
\hline & 30 & \multicolumn{3}{|l|}{$\begin{array}{l}\text { People in my country feel that it is important to } \\
\text { speak English. }\end{array}$} \\
\hline
\end{tabular}


Beliefs are seen as the strongest factors that can predict teachers' teaching behavior (Pajares, 1992). Thus, some researchers (Borg, 2005; Lee, 2009) started to identify the importance of investigating beliefs that not only related to their influence on the teaching behavior but also for forming part of the understanding process on how teachers conceptualize their work (Richards et al., 2001). Specifically, Icy Lee (Lee, 2009) stated that teachers who are willing to reflect their beliefs by identifying beliefs that do not support the studentss needs could assist them to identify contributed factors toward effective corrective feedback. The existing research mainly focused on teaching and learning process in similar situation, namely the same place for teaching and learning process. On the other hand, the current study investigated belief between lecturers at two different faculties in Unila. The faculties were FEB Unila and FKIP Unila, where in FEB the teaching and learning process of English teaching had different context with teaching and learning process of English teaching at FKIP Unila. This study is important reminisced that teachers in Indonesian context due to beliefs may differ across individuals as well as across contexts.

\section{Methods}

\section{Participants}

This study has been conducted in two faculties at The University of Lampung, namely FEB Unila and FKIP Unila. Two participants were selected to contribute to this study since they met the criteria of the chosen lecturer. They consisted of lecturers who taught English in different faculties at Unila. At the time of this study, first lecturer (L1) was graduated from English education department for her Undergraduate and master's degree and has been teaching English for ten years. Meanwhile, the second lecturer (L2), was graduated also from English education department for her Undergraduate Degree and graduated from Applied Linguistic for her master's degree. L2 has been teaching English for 6 years.

\section{Instruments}

This current study employed a case study research design with purposive sampling of its case selection. The case study ultimately fits to this research since case study focused on detailed investigation of specific instance of a phenomenon within "a bounded system over time, through detailed, in-depth data collection involving multiple sources of information and reported a case description and case-based themes (Creswell \& Tashakkori, 2007). It guided the researcher to compressively understand and describe related case to be provided as intelligible qualitative finding. In conducting this study, L1 and L2 were given questionnaire followed by in-depth interview (Lee, 2009). The interview had two major parts. 
The analysis of teaching belief between English lecturers at the Faculty of Economics and Business (FEB) and Faculty of Teacher Training and Education (FKIP) in the University of

The first part consists of items related to the belief of the explicitness, while the second part dealt with the factors that shape their beliefs during teaching and learning process in the class.

\section{Data Analysis}

The questionnaire data were taken from Horwitz's BALLI. Meanwhile, the interview data were analysed using data analysis technique by Creswell (Klassen et al., 2012) including preparing and organizing analysing the data, exploring, and coding the data, coding to build description and themes, representing and reporting qualitative findings, interpreting the findings, and validating the findings accuracy. Thus, to validate the finding's accuracy the researcher utilised: 1) member checking to confirm the data got from the participants, and 2) triangulation of sources and technique of collecting data by exploring two teachers using mixed-type questionnaire and followed by in-depth interview. The research questions that guided this study were as follows.

1. What are the lecturers' beliefs in teaching and learning process?

2. What are the factors that shape lecturers' beliefs in teaching and learning process?

\section{Results and discussion}

In this section, lecturers' belief regarding English teaching between two lecturers at two different faculties at Unila were highlighted into two themes as follows: (1) Lecturers' beliefs in teaching and learning process, and (2) The factors that shape lecturers' beliefs during teaching and learning process.

\section{Lecturers' Beliefs in Teaching and Learning Process}

In accordance with the data taken from the questionnaire, both lecturers had the same beliefs in teaching and learning process. The explanation of teaching beliefs held by both lecturers are divided into 5 themes as follows:

\section{Foreign Language Aptitude}

In this theme there are 9 statements related to a person's ability to speak a foreign language, in the context of this study is English. Of the nine statements, one statement is in the form of a choice which requires the lecturer to provide an answer based on the available choices, not an answer that judges agree or disagree. Based on the data under this theme, it can be said that the lecturers have the belief that everyone has good English language skills. For point 1, the lecturers gave agreed answers. Based on the results of the interview, the reasons given explain that children tend to have better memory levels than adults. Therefore, children tend to learn English more easily than adults. Furthermore, in point 2, the lecturers gave agree because it is related to the abilities of everyone which is 
different from one another, causing some people to have special abilities and some who do not have special abilities.

For point 10, all lecturers gave agreed answers. When viewed from the results of the interview, the reasons given explain that if someone can master a foreign language, then that person will have a better motivation to master another language. For item number 14 , the lecturers gave answer number 2, namely 1 to 2 years, and 5 to 10 years. One lecturer argued that to master English well, one must practice communicating in English more often. Furthermore, for point 21, all lecturers gave agreed answers on the grounds that the material from the Music or Movies are very helpful in creating fun activities in the classroom so that it doesn't make students feel bored. The other reasons which also stated was that the internet was also very helpful because it provided the availability of various and many sources of teaching materials. In contrast to point 28 , the lecturers tended to give disagreement. From the results of the interview, the reason is that reading, and writing did not require knowledge of good grammar, but speaking and understanding required knowledge of good grammar to produce good and understandable speech.

In point 31 there is a balance of answers between agreeing and disagreeing. L1 agreed that motivation is not the only reason for someone to master English, on the other hand, L2 disagreed the statement that in doing something someone needs motivation so that the goals you want to achieve can be achieved. Next, in point 32, the teacher gave an entirely agreed answer. One of the lecturers argued that good state officials in Indonesia seemed to master more than one foreign language. Other lecturers reasoned that everyone who mastered English would find it easy to master another foreign language. For the last point on this theme, lecturer who agreed argued that in learning English at the beginning, it was better not through translation, while lecturer who disagreed stated that translating language was part of learning to understand vocabulary and the meaning of what was said. Overall, lecturers believe that the students they teach have good English learning and speaking skills.

\section{Difficulty of Language Learning}

In the theme of difficulty of language learning, there are 6 statements consisting of five statements that require an answer to agree or disagree and one item of statement with five choices that must be chosen by the lecturers. From the overall statement, all lecturers did not judge English as a difficult language to learn. In point 3, L1 chose to agree and L2 chose to disagree. From the results of interviews, the reason stated was that English is used globally so that the learning process tended not to be too difficult. Furthermore, in point 4, both lecturers stated that English is a language that is easy to understand, but sometimes the difficulty of learning might occur because in learning English many students are not motivated. 
The analysis of teaching belief between English lecturers at the Faculty of Economics and Business (FEB) and Faculty of Teacher Training and Education (FKIP) in the University of

In statement number 6, L1 chose to agree while L2 chose to disagree. When viewed from the results of the interview, L1 thought that this is the goal of the learning process, but for the statement of disagreement, L2 tended to have a good opinion by saying that the students' speech depends on the abilities of different individuals. Furthermore, in point 23, all lecturers give an agree value. This clearly showed the desire of the lecturers that work with all the effort and put into the practice of teaching English in the classroom, all lecturers wanted their students to speak English well. In terms of the relationship between English and the ease of getting a job, both lecturers gave agree marks because by mastering good English it became a selling point for foreign companies. Finally, in this theme, number 34, all the lecturers gave agreed answers. This showed that English is a language that is not difficult and is used globally by many people, so that learning English will not be too difficult so that everyone who learns it would have success in speaking English.

\section{Nature of Language Learning}

In theme of nature of language learning there were seven statements with the choice of agreeing or disagreeing. Based on the questionnaire that has been distributed to both lecturers, in point $5, \mathrm{~L} 1$ gave the value agree and L2 gave the answer disagree. As a reason, English is learned from kindergarten, so that many Indonesians are fluent in English. In addition, L2 thought that Indonesian has a supportive aspect of the English pattern so that it is easy to learn. This causes many Indonesians to be fluent in English. Furthermore, in point 8, all lecturers agreed that the essence of learning English is to find out the culture of a country where most of the population speak English. This is intended to avoid misunderstandings in understanding cultures that are different from Indonesia.

Item 11 has the same number of agreed scores as number 10, in this case all scores fall into the agree category. For this reason, lecturers argued that learning English in a country where the population speaks English will speed up mastery of someone who is learning the language. The next number, number 15 , L1 argued that every human being has a unique ability to learn language, so that even learning English will emerge. On the other hand, L2 thought that in learning English, this special ability arises based on a person's interest and talent in learning English.

In responding to the level of error in learning English, both lecturers believed that errors are part of learning. When a student made a mistake in speaking English, it was better because the student was trying to make the utterance in English. For items 24 and 25, the lecturers equally gave agree and disagree. This was because in speaking a person did not need to really understand grammar, but in understanding speech, one needed to master grammar. Furthermore, in number 25, L1 argued that learning a language was not the same 
as studying other subjects. Language is something verbal and requires a process that involves everyone to be able to master it.

\section{Learning and Communication Strategies}

In the next theme, namely the theme of learning and communication strategies, there are eight kinds of statements related to several communication strategies and strategies to learn English. In this theme, lecturers tended to believe that learning English required strategies to support the achievement of goals.

In point 7, L1 agreed to believe that with good pronunciation, someone's speech could be easier to understand. On the other hand, L2 disagreed because in English, if the interlocutor understood what was being said, it was considered good, and good pronunciation was also relative. Furthermore, in point 9 all the lecturers gave a score for the category of disagree. This was because in learning English, a person or student must have the courage to use English as a means of communication. Using English as a habit would make these students mastered English faster. Mistakes were the process of learning English.

All lecturers gave agreed answers in point 12. The lecturers reasoned that through the practice of speaking with native English speakers it would be more quickly to encourage someone to master English. L1 argued that English could be mastered quickly if someone who is learning is not afraid to use it wrong in communicating. So, guessing was part of the learning process that tended to be done so that someone's goal of learning English could be achieved quickly.

In point 16 all lecturers agreed because in teaching English, vocabulary is the most important thing to start something. For example, in making sentences, vocabulary is required. If vocabulary is not taught, students would not be able to compose a sentence. Furthermore, for numbers 17 and 18, all teachers gave agreed answers to the two statements regarding practice and repetition and training (drilling) because these three things were important in the process of learning English. In the last statement on this theme, number 20, L1 argued that grammar was only a small part of English so that other things that were more important were prioritized to learn. L2 thought that listening and speaking skills were more important than grammar. In addition, if the student's goal was to pass the test, then grammar was indeed something that was considered important to learn in English.

\section{Motivation and Expectations}

In the theme of motivation and expectations, the acquisition of agreed and disagree values has a similar value, namely eight agrees and eight disagrees. This indicated that there were differences in the motivation given and the expected expectations which are normal. As in point 22, L1 tended to agree with the statement while L2 was disagree with the statement in number 22. This showed that $\mathrm{L} 2$ who disagreed would tend to give the same treatment to both genders in 
The analysis of teaching belief between English lecturers at the Faculty of Economics and Business (FEB) and Faculty of Teacher Training and Education (FKIP) in the University of

the process of learning English in the classroom. For number 26, L1 who gave agree argued that translating was also part of one's learning to master English. So, translating was considered something that could be done in the process of learning English.

Furthermore, in point 29, L1 gave agree and L2 gave disagree. This was because some students at FEB Unila who were also good at Statistics had good skills in learning languages. Finally, in point 30, both lecturers gave agree answer because by mastering English, the job will be better later.

From the results of the observations made, teaching beliefs were reflected in the practice of teaching, even though there were some beliefs that were still not reflected. However, overall, the belief was reflected in the practice of the teaching that is carried out. The unreflect belief was caused by several factors such as student characteristics that differ from one class to another, then the material being taught and the influence of the conditions in the class being taught.

\section{Factors that shape lecturers' beliefs in teaching and learning process}

Based on the results of the data gained through distribution of questionnaires and interviews, L1 and L2 agreed that academic background is the factor that shapes their current beliefs. L1 obtained her teaching experience when she was on her college. Her lecturer might not teach her about what method was perfect and how to do it. However, her lecturer asked T1 and her classmates to do peer practice in teaching. As she stated, "I ever did that in the college but, it is usually peer group of teaching. So, the practice would feel like a real classroom". This experience made her familiar with the actual teaching practice. Therefore, she adapted it for her teaching and learning process in her class.

Having different experience with $\mathrm{T} 1, \mathrm{~T} 2$ had bad experience in her teaching and learning practices during college. At that time, she felt burdened because she needed to teach in front of her classmates. She thought that teaching practice made her nervous because of the existence of the instructor who supervised and gave a lot of feedback during her teaching practice in front of the class. "For me, once there was an assignment about teaching practice. So many errors were made, it was already burdening me. There is so much to do; it turns out very complicated in English.” (Int2/T2)

That experience finally made her think how to teach English without making students feed burden. That was by employing selective teaching methods and approaches. Additionally, T2 mentioned that practical experience also plays a role in shaping her current beliefs. She felt that her first belief several years ago differs with her current beliefs. 


\section{Conclusion}

In conclusion, lecturers at FEB Unila and FKIP Unila held responsive and positive beliefs about English language teaching. Both lecturers tended to see English as a good language and quite easy to learn. The lecturers also believed that with strong motivation and determination, everyone who wished to master English will be able to master the language. In addition, there was a slightly difference between the existence of beliefs held by both lecturers and the real teaching and learning process. It was simply because the experience of teaching and learning process between L1 and L2 were different. In addition, a fun teaching practice would affect the existence of a good teaching and learning process done by lecturers or teachers to be in the future.

Our findings suggest that the possibility beliefs about learning and teaching may "unveil" lecturers' beliefs about knowledge and deserves more research attention. We believe there is still a need for more qualitative studies of teacher beliefs.

Finally, this research only focused on beliefs held by two lecturers at FEB Unila and FKIP Unila who has different type of students and situation of learning. At FEB Unila, unlike students from FKIP Unila, students were not talking and learning English all the time. The subjects might have different variations that at FKIP Unila most subjects were related to English while at FEB Unila most subjects were not related to English. Hopefully, the results of the research could give a different view about teaching belief in different context of teaching.

\section{References}

Alsamaani, A. (2012). Assessing Saudi learners' beliefs about English language learning. International Journal of English and Education, 1(2), 31-55.

Basturkmen, H. (2012). Review of research into the correspondence between language teachers' stated beliefs and practices. System, 4O(2), 282-295.

Borg, S. (2005). Teacher cognition in language teaching. In Expertise in second language learning and teaching (pp. 190-209). Springer.

Creswell, J. W., \& Tashakkori, A. (2007). Differing perspectives on mixed methods research. Sage publications Sage CA: Los Angeles, CA.

Donaghue, H. (2003). An instrument to elicit teachers' beliefs and assumptions. ELT Journal, 57(4), 344-351.

Horwitz, E. K. (1988). The beliefs about language learning of beginning university foreign language students. The Modern Language Journal, 72(3), 283-294.

Inceçay, G. (2011). Pre-service teachers' language learning beliefs and effects of these beliefs on their practice teaching. Procedia-Social and Behavioral Sciences, 15, 128-133.

Klassen, A. C., Creswell, J., Clark, V. L. P., Smith, K. C., \& Meissner, H. I. (2012). Best practices in mixed methods for quality of life research. Quality of Life Research, 21(3), 377-380. 
The analysis of teaching belief between English lecturers at the Faculty of Economics and Business (FEB) and Faculty of Teacher Training and Education (FKIP) in the University of

Kuntz, P. S. (1996). Beliefs about Language Learning: The Horwitz Model.

Lee, I. (2009). Ten mismatches between teachers' beliefs and written feedback practice. ELT Journal, 63(1), 13-22.

Pajares, M. F. (1992). Teachers' beliefs and educational research: Cleaning up a messy construct. Review of Educational Research, 62(3), 307-332.

Prosser, M., \& Trigwell, K. (1997). Relations between perceptions of the teaching environment and approaches to teaching. British Journal of Educational Psychology, 67(1), 25-35.

Richards, J. C., Gallo, P. B., \& Renandya, W. A. (2001). Exploring teachers' beliefs and the processes of change. PAC Journal, 1(1), 41-58.

Wang, J., Elicker, J., McMullen, M., \& Mao, S. (n.d.). Chinese and American preschool teachers" beliefs about early.

White, M. J., \& Bruning, R. (2005). Implicit writing beliefs and their relation to writing quality. Contemporary Educational Psychology, 3o(2), 166-189. 